\title{
The Prophetic Reason for Religious and Cultural Understanding
}

\author{
Manuel Losada-Sierra, Griffith University, Australia \\ John Mandalios, Griffith University, Australia
}

\begin{abstract}
Interreligious and intercultural dialogue is supposed to be the best way to solve the conflicts arising from rival religious hermeneutics and different modes to conceive the ideal of a good life in contemporary multicultural and pluralistic societies. In regard to communicative or dialogical reason, respectful coexistence can be reached only by argumentative communication between interested people. In this sense, only rational arguments, strong enough to pass the test of the shared rationality can be valid at a discursive level. However, Jewish philosopher Emmanuel Levinas and Catholic theologian Johann Baptist Metz challenge symmetrical and rational-based dialogue in order to postulate an asymmetrical relationship by giving voice to the other. For them, the core of interreligious and intercultural engagement does not start from rational agreements as Habermas, for instance, has proposed; but from prophetic and anamnestic reasons. This analytical and comparative presentation will show the possibilities of anamnestic reason and religion as service against dialogical reason in intercultural and interreligious contexts. Levinas's and Metz's criticism of dialogical reason opens new perspectives which contribute to reflection for both political theology and political philosophy.
\end{abstract}

Keywords: Levinas, Metz, Religion, Culture, Dialogue, Prophetic Reason

\section{Introduction}

$\mathrm{O}$ ne of the relevant characteristics of contemporary societies is the coexistence of cultural and religious pluralities and therefore, the coexistence of different ways of relating to God and conceiving the ideal of a good life. It is commonly held that faith provides meaning for life and cultural roots for many people, but sometimes customs and beliefs derived from cultural traits can lead to suspicion, discrimination and segregation. This is the reason that multicultural societies experience the challenge to find the best way towards a respectful and fruitful way to live together. In this regard, the following questions arise: How to deal with the difficulty of inter-religious and inter-cultural coexistence so that different religious hermeneutics do not result in violence and discrimination? How to build scenarios of inclusion, collaboration and integration? How can mutual respect beyond dogmatic concepts that ground religious traditions be achieved? To respond to these questions, this discussion will show the possibilities of the prophetic reason that challenge the intersubjective-symmetrical relationship by giving priority to the other. Emmanuel Levinas's and Johann Baptist Metz's criticism of dialogical reason opens new perspectives which contribute to reflection for both political theology and political philosophy.

Tolerance was the answer to eliminate cruelty in the relations between different faiths in the violent wars of religion in Europe during the XVI and XVII centuries. Tolerance has also been the grounds for dialogue and also the most important scenario that activists (both political and religious) and thinkers have found to overcome conflicts and to find similarities that help religious and cultural communities understand each other. Generally speaking, dialogue takes place in an inter-personal encounter with the aim of reaching an understanding that favours scenarios of consensus and harmony (Habermas 1985, Rorty 1992, Gadamer 2004).

Dialogical proceduralism, however, has been challenged by theologian Johann Baptist Metz and philosopher Emmanuel Levinas from the perspective of the prophetic reason. The Prophetic rationality is a mode of thinking coming from the Judaic wisdom that grants a privilege to the external other and philosophically attempts to defend the place of the other in the ethical relationship. This is a post idealistic and post ontological way thinking that claims the Jewish heritage as primary and fundamental in relation to Greek-philosophical heritage in the Western world.

The International Journal of Civic, Political, and Community Studies

Volume 11, 2014, www.thehumanities.com, ISSN 2327-0047

(C) Common Ground, Manuel Losada-Sierra, John Mandalios, All Rights Reserved

Permissions: cg-support@commongroundpublishing.com 
The following discussion examines the possibility of building a new form of understanding regarding religious and cultural encounters based on the prophetic rationality. To do so, the discussion starts from the perspective of (i) the dialogue or communicative reason (ii) to examine the proposals put forward by Metz and (iii) Levinas, with the purpose of (iv) pointing out ideas from Levinas and Metz that could support cultural and religious understanding.

\section{Communication between Religious Worlds in a Multicultural Society}

The dialogue between cultures and religions has been an important source of discussion for both philosophers and religious thinkers. From a theological perspective, at least from the 1960's of the XX century, the number of ecumenical networks, documents, books and inter-religious meetings has been gradually growing. Swiss theologian Hans Küng is one of the leaders of this ecumenical movement. He considers that only through achieving peace between religions is it possible for there to be peace in the world. Kung claims that religions "should stress what they have in common more strongly than what divides them" (1993, xviii). He is convinced that dialogue is the best way to reach this objective. In addition, from a philosophical standpoint, the place of religion in contemporary societies has also been an object of discussion in seeking to answer two questions: whether religion has relevance in the public sphere and therefore, whether religion has the epistemological tools for discussion between religious and non-religious citizens in a liberal society, and, in the second place, how to respect different religious perspectives in a pluralistic and multicultural society.

Jürgen Habermas, one of the most influential contemporary philosophers, points to a procedural instrument of dialogue based on human rights in order to build a transnationalintegrated global society. Habermas considers that it is time to take steps towards a multiculturalliberal constitution that does justice to an increasingly culturally-diverse society. Basic human rights are universally valid and rationally motivated and, according to Habermas, they are the grounding for a fruitful dialogue in order to reach consensus and "weak agreements" about justice in multicultural societies (Habermas 2008b, 14).

In terms of religious and cultural understanding, this proceduralism rests upon two cognitive assumptions: (i) everyone involved in the dialogue must consider the controversial topics from their own standpoint and also from that of the other participants; and (ii) only universalising arguments count in this dialogue, that is, arguments that could convince everyone irrespective of religious and cultural backgrounds. While the first assumption considers the mutual respect and cooperative attitude of the participants in the dialogue, the second points to a rational universe of discourse that allows participants to limit themselves to arguments which are potentially consensual. As a consequence of these dialogical conditions an ideologically neutral agreement could be reached, and therefore a secular level of understanding (Habermas 2008b, 11).

Therefore, in regard to communicative or dialogical reason, respectful coexistence can be reached only by argumentative communication between interested people. In this sense, only rational arguments, strong enough to pass the test of the shared rationality can be valid at discursive level. Questions arise, therefore, about the risks of dialogical reason. In the first place, the risk of rhetoric and instrumentalization is always present (Salvarani 2011), and in particular, as is the failure to take into account the weak, the victims and those who cannot argue or are not present (Metz 1998).

According to Metz, this communicative reason is not enough to universalize justice and solidarity. This is because communicative reason only accepts what is metabolizable in a shared rationality and fails to take into account the weak, the victims and those who cannot argue or are not present. That is, when facing questions from victims who have suffered an unjust violence, consensus or horizontal communication is worth very little; what matters is to respond to their suffering and injustice. The reason of the defeated is a cry, a denunciation, a demand for justice, and its strength comes from the experience of injustice and not from communication or 
persuasive power. This is the anamnestic rationality, akin to Benjamin's Eingedenken, that is, the memory of the victims (die Leidensgeschichte) rather than the winners. The universality of responsibility arises from this memory, and becomes the greatest asset of monotheism.

Concerning the possibility of a multicultural-integrated society, a new inquiry arises: might the suffering of the victims bring diverse religious and cultural worlds together? For Habermas, integration is only opened by a communicative interaction, as stated above. If, on the contrary, according to Habermas, each culture is supposed to exist for itself as a semantically sealed whole, cut off from dialogues with other cultures, this integration would not be possible as a result of the semantic closure of immeasurable worldviews. However, Metz considers that a different way of integration is possible and, therefore, the communicative action no longer has the last word.

\section{The Authority of the Victims}

Metz considers cultural and religious pluralism one of the "discussions of the times" to which political theology has to offer relevant reflection (Metz 1999, 227). In the face of pluralism, Metz uncovers an aporia in contemporary society. While any attempt to universalise is seen as totalitarian and anti-pluralistic, the solution for the problems of the techno-scientific reason lies beyond the capacity of the individual. For this reason, he formulates the following question: "given the undeniable diversity of cultural and religious worlds, is there still a universal binding and thus plausible criterion for understanding?" (Metz 1999, 228).

As stated above, Habermas finds that dialogical communication, in which partners can share arguments and reach a consensus in a symmetric position through a dialectic process, is the way to any possible understanding. If this way is closed, the alternative for Habermas is a solution à la Carl Schmitt that is the constitution of a powerful and decisionistic state to hold back the danger of war (Habermas 2008b, 13; Schmitt 1991). The way of understanding however is open, according to Metz, and Carl Schmitt does not have the last word in the face of the incommensurability of worldviews.

\section{Universal Binding and Criterion for Understanding}

Via criticizing the two different modes to respond to the problem of multiculturalism, Metz reacts to the aporia of pluralism and universalism from the religious roots themselves. In the first place, Habermas's dialectic-discursive encounter is insufficient and proceduralism shows a dark shadow, according to Metz. This dark shadow has to do with the contemporaneity and symmetry of interlocutors in order to reach a universal consensus (Metz 1998, 142; 2005, 286-87). In fact, dialectic discourse is based on the structure of mutual recognition and exchange and, in this sense, discourse participates both in Hegelian's idealism of the transcendental equal status of the partners and in the enlightened society of exchange. Secondly, in Western cultural circles many people favour a religion without God (Metz 1998, 155-56; 1999, 229). Even though this approach seems to be a softer and more tolerant religious paradigm that is appropriate for this pluralistic age, Metz takes issue with it in order to postulate grounding from the religious traditions themselves.

Furthermore, Metz is clear that universal moralism is not the result of basic consensus or minimal meanings, as has been stated by theologian Hans Kung. According to Kung, in the face of the incommensurability of worldviews, the purpose of religious dialogue is to find a basic consensus that roots global ethos and therefore reach an agreement on the common values that could be meaningful for all religions. However, neither Habermas's or Apel's argumentative competence nor Kung's basic consensus are strong enough to universally bind interreligious understanding. Metz considers that only in an asymmetrical relationship would a fruitful interreligious and intercultural mode of life be possible. 


\section{The Authority of Those Who Suffer}

Being that consensus and argumentative competence are insufficient reasons for the imperative necessity of the universal binding for religious togetherness, Metz's political theology has to consider an authority that has to be acknowledged by all religions. This is the authority of those who suffer as innocents, unjustly. The struggle for justice can generate a "horizontal horizon" in which religions can encounter themselves resisting unjust suffering. In this horizon an indirect ecumenism of religions is defined by Metz.

Looking at the place suffering has in Metz's political theology is basic for comprehending the significance of indirect ecumenism. The authority of those who suffer is so strong that the basis of all morality could be lost when the obedience to discourse and communication has primacy over the suffering, and therefore "this authority can no longer be shaped by hermeneutics or be safe by discussion" (Metz 1999b, 232). This authority is a source of meaning for ethics and, therefore, for individual and institutional behaviour. In fact, the obedience to this authority tests the righteousness of any ethics that do not want to become "ethics of accommodation" or justification, meaning an ethic "that seeks to reconciliate human actions with everchanging practical circumstances" (Metz 1999, 232). This authority, furthermore, makes universal human rights possible, which is regarded by Habermas as basic for universal religious understanding, and cultural differences can be tied to one another to avoid the eruption of more violence.

The authority of the suffering takes the form of memory. This memory is a different rationality that is a different mode of thinking with a different origin from that of the instrumental rationality. In fact, in a world in which instrumental and pragmatic rationality is spread everywhere and therefore human relationships are based on production and effectiveness, anamnestic rationality saves the memory of the losers and those defeated in history. The memory of the victims forces us to look at history not merely from the standpoint of the successful but from that of the conquered and victims (Metz 1980, 105).The past of the victims is full of meaning because it is recognised as an injustice that questions the present. These are dangerous memories because they visit the present and question it. These could be subversive memories with a liberating message for the future. It is necessary, therefore, to take a look at the vanquished and the defeated in history and develop a kind of anti-history.

Furthermore, memory is fundamental for the constitution of the subject. In fact, it is a category of salvation for a threatened subjectivity. According to Metz, it is not by chance that any totalitarian rule begins with the destruction of the memory. Amnesia is indeed the consequence of mechanisms that control the dominant consciousness which equates everything outside of the pragmatic reason with superstition. On the contrary, these memories take the form of liberating narratives; they are essentially practical, and not merely argumentative.

\section{Universal Solidarity and Resistance}

As stated above, encounters between religions and cultures take shape thanks to the recognised moral and cultural authority of the suffering that disturbs the present. As a consequence of this approach, the framework of religious encounters is common practical work, a common response, and a common resistance to the sources of unjust suffering in the world. These sources could take the form of xenophobia, segregation, discrimination and ethnic-centred religiosity (Metz 1999b, 233). This common resistance also points to the consequences of the instrumental rationality that increasingly causes human beings to vanish amid the systems of technology, economy, market and communication industries. Therefore, religion must be both a resistance against cultural amnesia and struggle for the recognition of the victims. Religion should be nothing else than the mouthpiece for the innocent victims of history who have been destroyed and can no longer speak for themselves. This common resistance is a universal responsibility for all religions towards the weak and those who do not count in society. 
To Metz, universal responsibility is rooted in biblical traditions. Jesus looking first to the suffering and not to the sin is the grounding for the Christian perspective of the community of memory. The Christian community acts as a community of the imitatio Christi that is the community that follows the paths of Jesus. From a biblical perspective, even the suffering of enemies must be taken into account because it is not up to us to define clearly and to delimit the range of this responsibility or the breath of this caring. The neighbour of the Parable of the "Good Samaritan" "is never only the one whom we ourselves regard and accept as such" (Metz 1999b, 230).

This is the reason why Metz states that "the ethnic-cultural diversification of our world and its cultural polycentricism can be saved only in the face of a civilization of world unity without substance, if, in so-called intercultural exchange, the Geisteswissenschaften elaborate and hermeneutically secure the communicative superiority of the language of memory against the subject-less language or argumentation of Greek metaphysics and also of the predominant scientific language of Occidental rationality" $(2005,288)$. Certainly, this universal responsibility is close to Levinas's religion as diakonia. From Metz's and Levinas's perspectives the most important factor is the way in which religion responds to the other's sufferance and misery, and not the dogmas, administrative organization or preoccupations for the salvation of the soul.

\section{The Diacrony of the Diakonia: Religion as Service}

Levinas is convinced that it is possible to have a common framework in which "to think in a universal human society that incorporates the just people of every nation and every belief, with whom it is possible to achieve the final intimacy" (Levinas 1997, 163). Levinas's approach to the dialogue of transcendence and the concept of religion as praxis in favour of social justice are ideas that after being elucidated will show an ethical way that leads to a common space of encounter for all cultures and religions.

\section{The Dialogue of Immanence}

In line with his criticism of Western thinking for its connatural tendency to assimilate knowledge with understanding, Levinas finds that dialogue, as an interchange of ideas and words in a symmetrical position, is an attempt to comprehend the other and thus to compress the other within the knowing consciousness. The fundamental conjuncture of the human is not the agreement of men around shared ideas. This is an exercise of knowing the other as an object and it is therefore a victory of the Hegelian absolute thought and the Cartesian "I think". With irony, Levinas affirms that this is the "path of predilection of western humanism", through which it wants to overcome violence $(1998,141)$. This is a dialogue of immanence because it keeps the other inside the subject's consciousness in the dynamism of reciprocity in which the logic of commercial exchange prevails.

In this kind of dialogue, Levinas recalls the danger of rhetoric: "the seducer knows all the ploys of language and all its ambiguities. He knows all the terms of dialectic. He exists precisely as a moment of human freedom, and the most dangerous of seducers is the one who carries you away with pious words to violence and contempt for the other man" (Levinas 1999, 177). In Levinas's opinion the problem is not only the use of strategic dialogue to manipulate the coparticipants in the dialogue. Levinas's claim is more profound insofar as it has to do with the ethical constitution of the subject in which there is an absolute separation between the "I" and the "you", where the "I" feels the summons to respond for the other. For Levinas, the relationship that constantly reinstates the humanity of man is not the formal structure of reciprocal relationships in which the "I" is a "you" for the other and the "you" is discovered to be another "I". Beyond the reversibility of the structure, Levinas wants to find asymmetrical ethical 
relationships, which consists for the I in 'going toward the Other where he is truly other' (Levinas 1999, 88).

Furthermore, the ethical transcendence that springs up in the interpersonal relationship indicates that the egalitarian and reciprocal relationship is not the ultimate structure of the human. The structure of the Buberian "I-Thou" is not the originator and cannot constitute the ethical. So, it is the infinity of the face to the other man, which is the living refutation of the pretension of the social totality, the economic and administrative structure, to be sufficient unto itself.

\section{The Dialogue of Transcendence}

Levinas transforms the meaning of the word dialogue from the way it is used in Western thinking. Dialogue is no more a mode of speaking but instead "a thinking of the unequal, a though thinking beyond the given [...] the modality according to which in dialogue, or more precisely in the ethics of dialogue, in my deaconships with respect to the other, I think more than I can grasp" (Levinas 1998, 151). By transforming the concept of dialogue, Levinas uncovers an ethical dimension that breaks up the spoken dialogue because the face-to-face already speaks before any word.

From Levinas's point of view, not only closeness but absolute transcendence or alterity of the "you" in regard to the "I" constitutes an authentic dialogue. The relationship with the other cannot be on the same level because there is no possibility of comparison between the subject and the other, that is, the last foundation of this relationship is not a common participation in being. This is because language is, according to Levinas, the ethical questioning of the self, coextensive with the manifestation of the other in the face. In this sense,

language conditions thought -not language in its physical materiality, but language as an attitude of the same with regard to the Other, irreducible to the representation of the Other, irreducible to an intention of thought, irreducible to a consciousness of..., [...] Language is not enacted within a consciousness; it comes to me from the Other and reverberates in consciousness by putting it in question (Levinas 1969, 204).

Furthermore, Levinas's account of dialogue opens the way to transcendence and the infinite. In the face of the other is found the trace of the infinite. For Levinas, the problem of transcendence and God runs parallel with the problem of subjectivity irreducible to the essence, to the immanence. The Cartesian idea of infinity in which ideatum exceeds the idea is the clue to understand the transcendence of the other which, for Levinas, recalls the transcendence of God. This is the way to comprehend the inequality between the "I" and "you". The service to the other is the first liturgy, the first prayer. Religion is service and not sacredness. Dialogue is rather a requirement of holiness; it is the testimony of the infinite and transcendence.

\section{Religion as Diakonia}

In a talk titled "Israel and Universalism" in response to Father Jean Danielou's speech on the common foundations of Mediterranean Civilization, Levinas observes that the problem of truth in religious understanding is not a real problem for Jewish people because truth is not a problem of dogma but a problem of action (Levinas 1997, p. 176). In the meeting, Father Danielou had pointed out that religions, when confronted with others, are thorns between truth and charity. According to Levinas, religion is essentially a problem of justice and the dimension of the divine is open forth from the human face. This means that "God rises to his supreme and ultimate presence as correlative to the justice rendered unto men" (Levinas 1969, p. 78). The relationship with God cannot be accomplished in the ignorance of men. Therefore, the relationship with God 
is established in the field of ethics and not in that of knowledge. In this sense, the relationship with God makes sense

in the proximity of the other man who is stranger and possibly naked, destitute and undesiderable, but that it signifies also in his face that ask for me [...] all this must not be taken as 'a new proof of the existence of God.' [...] All this describes only the circumstance in which the meaning itself of the word 'God' comes to mind" (Levinas 1998, 168).

To Levinas, there is not a direct relationship with God; it is only possible to hear His call in the face of the Other who summons the subject from his/her destitution and neglect. This is the non-indifference before the ungraspable and unrepresentable, before the Other who appoints the subject "as unique and elected" without possible evasion (Levinas 1998, 177). In ethically understanding the relationship with God, Levinas is able to call "religion" the tie established between the same and the other without constituting a totality. In other words, religion means transcendence or proximity to the absolutely Other.

From the discussion above, it can be understood that proximity is not simple tolerance, neutrality or non-aggression in relation to the Other. The consequence of Levinas's stance is a universal responsibility. This is the essential message of Judaism which signifies universally. Far from ethnic particularism, Levinas is convinced that biblical messages signify all human thought, for all civilizations, because they can be recognised in peace and in the responsibility of one man for another. According to Levinas, the prophets preoccupied themselves with the poor, the widow, and the stranger and not with the immortality of the soul. Religion is a service, a diakonia, toward those who are in need. Therefore, religion as a struggle for a just society is universal because not interfering with dogmas makes sense even when the problems are insoluble.

Concerning the insoluble problems, Levinas is aware that the mechanism of dialogue and looking for the most-common-denominator platform is sometimes insufficient. The problems persist and history cannot reconciliate everything that is waiting to be solved from reason, technology or dialogue. The better way is "a proximity that lasts even after dialogue has become impossible" (Levinas 1999, 87). This proximity is the only possible attitude towards the insoluble problems between cultures and religions, and proximity means a universal responsibility towards the material needs of the neighbour.

In this regard, Levinas recalls a biblical and Talmudic tradition relating to Abraham. When Abraham received the three angels in his tent, he was convinced that the passers-by were Bedouins, from the Negrev Desert, that is Arabs. He ran toward them and called them "Your Lordships". To Levinas, this is a sign that the heirs of Abraham are of all nations: "any man truly man is no doubt of the line of Abraham" (Levinas 1994, 99). The responsibility, that is, the obligation to feed the other is universal and has no limits.

\section{Conclusion}

In a world characterised by globalisation and the presence of different "modernities" (Eisenstadt 2000), religion is able to provide a sense of cultural belonging and, at the same time, hermeneutical roots to justify violence both explicitly and subtly. In the face of dialogical reason, supposedly established in order to overcome the consequences of that violence, Catholictheologian Metz and Jewish-philosopher Levinas share the same preoccupation about the sufficiency of dialogical proceduralism.

Having criticised the predominance of Greek thinking into theology, in the case of Metz, and into philosophy, for Levinas, they postulate an authority in order to support a strong horizon of comprehension for interhuman encounters. This is because transcendental theology and philosophy end in idealism and ignore the concrete reality in which there is multiplicity and from 
which all meaning is established. Metz considers that suffering is the criteria to decipher where this authority comes from, and Levinas, in turn, appeals to the revelation of the Other that summons individual responsibility. While Metz grounds his claim historically, that is in the power of the past over the present, Levinas sets up his responsibility in a diachrony in which the relationship is saved from totalisation. Diachrony makes possible that interhuman relationships happen as a summons from above and not from the other side. The rapport is non simultaneous and non-present, it is beyond history and therefore irreducible to the synchrony of the same. Despite these theoretical differences, an agreement can be found. For Metz and Levinas, interhuman relationships and any possible interreligious encounters have a concrete response: the responsibility for the other who claims from its suffering and from its material needs.

Apart from having the normal differences between a Catholic and a Jew, Metz and Levinas are also both profound believers in their respective religions, are both considered unorthodox and identify true religion with praxis in favour of the other. In religion, the horizontal dimension is the criteria for a true relationship with God. That is, the service to the neighbour is the way to reach God. This dictum is more radical in Levinas who considers that going towards God is meaningless unless seen in terms of the primary going towards the other person. The invisible God is present only in the face of the other.

Therefore, this paper has suggested, from Levinasian phenomenology, that religion conceived as diakonia, and the invisibility of the face of God becoming present in the human face regardless of particular beliefs, are categories that would support a proposal for integration between different religious perspectives to overcome the weaknesses of dialogical reason. Furthermore, Metz's call for universal justice stemming from memoria passionis could ground cultural and religious exchange in history. In this sense, the remembrance based on the suffering of victims overcomes the danger of the oblivion of past suffering and prevents a purely technical understanding of freedom and peace. The shift from Habermasian dialogical reason to prophetic reason in Metz and Levinas could be described as a shift from thinking with another to acting in favour of another. 


\section{REFERENCES}

Buber, Martin. 1996. I and Thou. Translated by Walter Kaufmann. New York: Simon \& Schuster Cortina, Adela. 2000. Ética Mínima: Introducción a la Filosofía Práctica, 6th ed. Madrid: Tecnos.

Derrida, Jacques. 2002. Acts of Religion. Edited by Gil Anidjar, New York: Routledge.

Eisenstadt, Shmuel Noah. 2000, "Multiples Modernities." Daedalus, 129(1): 1-29, doi: $10.2307 / 20027613$.

Gadamer, Hans-George. 2004, Truth and Method. London: Continuum.

Habermas, Jurgen. 2005. "Israel and Athens, or to Whom Does Anamnestic Reason Belong?" In The Frankfurt School on Religion: Key Writings by the Major Thinkers, edited by Eduardo Mendieta, 293-301. New York: Routledge.

Habermas, Jurgen. 2008a. Between Naturalism and Religion: Political Essays. Translated by Ciaran Cronin. Cambridge, UK: Polity Press,

Habermas, Jurgen. 2008b. "El resurgimiento de la Religión, ¿Un reto para la auto comprensión de la modernidad?" Dianoia, LIII(60): 3-20.

Kung, Hans. 1993, Global Responsibility. Translated by. John Bowden. New York: Continuum.

Levinas, Emmanuel. 1969. Totality and Infinity: An Essay on Exteriority. Translated by Alphonso Lingis. Pittsburgh: Duquesne University Press.

Levinas, Emmanuel. 1991, Otherwise than Being or Beyond Essence. Translated by Alphonso Lingis. Dordrecht: Kluwer Academic Publishers.

Levinas, Emmanuel. 1994. Nine Talmudic Readings. Translated by Annette Aronowicz. Bloomington: Indiana University Press.

Levinas, Emmanuel. 1997. Difficult Freedom: Essays on Judaism. Translated by Sean Hand. , Baltimore: The John Hopkins University Press.

Levinas, Emmanuel. 1998. Of God Who Comes to Mind. Translated by Bettina Bergo, Stanford: Stanford University Press.

Levinas, Emmanuel. 1999. Alterity and Transcendence. Translated by Michael B. Smith. New York: Columbia University Press.

Marcuse, Herbert. 1969. "Repressive Tolerance," In A Critique of Pure Tolerance, edited by Wolff, Robert, Barrington Moore, and Herbert Marcuse. 95-137. Boston: Beacon Press.

Metz, Johann Baptist. 1980. Faith in History and Society. Translated by David Smith. New York: The Seabury Press.

Metz, Johann Baptist. 1998. A Passion for God. Translated by J. Mattew Ashley. New York: Paulist Press.

Metz, Johann Baptist. 1999a, Por una cultura de la memoria. Translated by José M. Ortega Barcelona: Anthropos.

Metz, Johann Baptist. 1999b. "In the Pluralism of Religious and cultural Worlds: Notes Towards a Theological and Political Program," Cross Currents, 49(2): 227-236.

Metz, Johann Baptist. 2005. “Anamnestic Reason: A Theologian's Remarks on the Crisis in the Geisteswissenschaften." In The Frankfurt School on Religion: Key Writings by the Major Thinkers, edited by Eduardo Mendieta, 285-289. New York: Routledge.

Popper, Karl. 1971. The Open Society and its enemies. Vol. 1. Princeton: Princeton University Press.

Rorty, Richard. 1992. The Linguistic Turn: Essays on Philosophical Method. Chicago: University of Chicago Press.

Salvarani, Brunetto. 2011. Il dialogo e finito? Ripensare la Chiesa nel tempo del pluralismo e del cristianesimo globale. Bologna: Edizione Dehoniane.

Schmitt, Carl. 1991. Völkerrechtliche Grossraumordnung mit Interventionsverbot fürraumfremde Mächte. Ein Beitrag zum Reichsbegriff für Völkerrecht. Berlín: Duncker and Humboldt.

Walzer, Michael. 1999. On Toleration. New Haven: Yale University Press. 
THE INTERNATIONAL JOURNAL OF CIVIC, POLITICAL, AND COMMUNITY STUDIES

\section{ABOUT THE AUTHORS}

Manuel Losada-Sierra: PhD Student, School of Humanities, Griffith University, The Gold Coast, Queensland, Australia.

John Mandalios: Senior Lecturer, School of Humanities, Griffith University, The Gold Coast, Queensland, Australia. 
The International Journal of Civic, Political, and

Community Studies is one of five thematically focused journals in the collection of journals that support the New Directions in the Humanities knowledge community -its journals, book series, conference, and online community.

Studies in the humanities frequently analyze the processes and dynamics of civil society, political orientations and community engagements. This journal explores the interdisciplinary space where the practices of the humanities intersect with the methods and concerns of the social sciences

In addition to papers of a traditional scholarly type, this journal invites case studies that take the form of presentations of practice-including documentation of socially-engaged civic, political, and community practices, together with exegeses analyzing the effects of those practices.

The International Journal of Civic, Political, and Community Studies is a peer-reviewed scholarly journal.

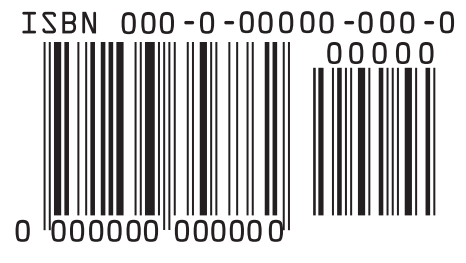

